Original Article

\title{
ANTIMICROBIAL PROPERTIES OF LEPTADENIA HASTATA (PERS) DECNE LEAVES EXTRACT
}

\author{
ISAAC JOHN UMARU ${ }^{\mathrm{ab}}$, FASIHUDDIN A. BADRUDDINa , ZAINI B. ASSIMa , HAUWA A. UMARUc
}

aFaculty of Resource Science and Technology Sarawak, Kuching, 94300 Kota Samarahan, bepartment of Biochemistry, Faculty of Pure and Applied Science, Federal University Wukari Taraba, cDepartment of Biochemistry Moddibo Adama University Science and Technology Adamawa Email: umaruisaac@gmail.com

Received: 24 Nov 2017 Revised and Accepted: 03 Jan 2018

\section{ABSTRACT}

Objective: This study was carried out with an objective to investigate the antibacterial potential of five leaf extract of Leptadenia hastata plant on some bacteria.

Methods: Leptadenia hastata extracts were evaluated for potential antimicrobial properties. The leaves of the plant were extracted with n-hexane, dichloromethane, ethyl acetate, chloroform and methanol and then vaporized to give respective extracts. Antimicrobial activity against Escherichia coli, salmonella typhi, staphylococcus aureus and Klebsielia pneumonia, was determined by an agar well diffusion method. The optical density of the broth using UV mini spectrophotometer and zone of inhibition by the crude extract were determined.

Results: The results showed that of n-hexane, ethyl acetate, dichloromethane and methanol extracts of Leptadenia hastata, methanolic and chloroform extracts displayed more activity with $1.10 \pm 0.10 \mathrm{~mm}^{\mathrm{ab}}$ and $0.97 \pm 0.06 \mathrm{~mm}^{\mathrm{ab}}$ where aSignificantly ( $<<0.05$ ) higher compared to different extract at the same concentration ${ }^{b}$ Significantly $(\mathrm{p}<0.05)$ lower compared to the control, than others at $25-1000$ ppm per well of the extracts tested.

Conclusion: The present results showed the potential of the medicinal plant used by traditional herbal medical practitioners as natural antimicrobial agents, thus can be further used to determine the bioactive products that may provide as leads in the development of new drugs.

Keywords: Escherichia coli, Salmonella typhi, Staphylococcus aureus, Klebsielia pneumonia, Leptadenia hastate

(C) 2018 The Authors. Published by Innovare Academic Sciences Pvt Ltd. This is an open access article under the CC BY license (http://creativecommons.org/licenses/by/4.0/) DOI: http://dx.doi.org/10.22159/ijpps.2018v10i2.23929

\section{INTRODUCTION}

Natural products have been used over the years as curative agents against many infections and have been exploited in the traditional medicine with their curative potentials well documented [1-3]. Natural products are defined as natural sources-derived substances having biological activities. These natural products have long been implemented as alternative health care treatment and in the discovery of modern drugs [4]. A major focus of natural product in chemistry has been toward drug design and discovery. However, obtaining scientific proof for the biological activity of natural plants is still challenging $[5,6]$.

Leptadenia hastata despite the extensive uses, there have been only limited attempts to explore the biological activities of the plants in relation to their medicinal uses. It was reported that traditional healers use 2,500 plant species as regular sources of medicine [28]. Here, we present data on antimicrobial activities of the different extracts obtained from n-hexane, dichloromethane, ethyl acetate, chloroform and methanol of Leptadenia hastata plant species.

Leptadenia hastata (Pers.) Decne, which belongs to the family Asclepiadaceae, is a wild plant used as a vegetable by many African populations and as medicine due to its nutritive and therapeutic properties for the treatment of wounds and stomach upset conditions in children $[7,8]$. The plant Leptadenia hastata is an edible non-domesticated valuable herb with creeping latex stems, glabescent leaves, glomerulus and recemes flowers as well as follicle fruits. It is typically grown in tropical dry land in sand soil [9].

The plant is commonly used in the north Nigeria as spices and sauces [10]. Local healers also use the plant for hypertension, catarrh and skin diseases [11]. It is commonly used as a vegetable and is considered as a famine food in Niger republic due to its high content of valuable nutrients rich in various types of amino acids, fatty acids, terpenes, carotenes, luteines and poly-oxy pregnane [10, 12-14]. In certain areas of West Africa, breeders claimed the antifertility effect of their animals after consumption of the leaf and stems of Leptadenia hastata [1, 15]. The main phytochemical constituents of the plant are carbohydrates, steroids, glycosides, flavonoids, tannins, and phenolic compounds [29]. This study was carried out with an objective to investigate the antibacterial potential of five leaf extract of Leptadenia hastata plant on some bacteria. The findings in this study may contribute to the present literature in understanding the bioactive value of the crawling plant Leptadenia hastata.

\section{MATERIALS AND METHODS}

\section{Chemicals}

All chemicals used in this investigation were of analytical grade and were obtained from SIGMA. Standard antibacterial agent $(30 \mu \mathrm{g})$ tetracycline, antimicrobial susceptibility test discs and Nutrient agar (CM0003) were obtained from Oxoid Ltd, Wade Road, Basingstoke, Hants, RG2 8PW, UK. oxoid@oxoid.com.

\section{Sample collection}

Leptadenia hastata leaves: freshly leaves of Leptadenia hastata were collected from the uncultivated farmland of the Federal University Wukari Taraba State, Nigeria and was authenticated at Ahmadu Bello University Zaria and Voucher No PU: 2 ABU Herbarium No 900220. The plant Leptadenia hastata (yadiya) was dried under room temperature.

\section{Preparation of samples}

Fresh leaves of the plant Leptadenia hastata was washed with distilled water to remove the soil and dust particles, they are thoroughly air dried and powdered using laboratory grinder machine (FGR-350, Quest Scientific). Extraction using hexane by placing $150 \mathrm{~g}$ of the powdered samples into an Erlenmeyer flask and hexane three times the weight of the extracts was added, the solution was covered and shaken at an interval of an hour and then allowed at room temperature to stand for 7days. The mixture was then filtered using Whatman filter paper No.4 the residue was reextracted with fresh hexane for another $72 \mathrm{~h}$ and filtered. Both extracts were combined and concentrated with a rotary evaporator (Heidolph Laborota 4000 efficient) under reduced pressure to 
obtain the hexane crude extract. The residues were re-extracted using a similar procedure with dichloromethane $\left(\mathrm{CH}_{2} \mathrm{CL}_{12}\right)$, followed by ethyl acetate $\left(\mathrm{C}_{2} \mathrm{H}_{5} \mathrm{COOH}\right)$, chloroform $\left(\mathrm{CHCL}_{3}\right)$, and methanol $(\mathrm{MeOH})$ to obtain dichloromethane, ethyl acetate, chloroform and methanol crude extracts, respectively. The dry weight and yield of each crude extracts were determined. It was then stored under a frozen condition until required.

\section{Antimicrobial assay}

Antimicrobial assays were conducted using the agar well disk diffusion method, Nutrient agar was used as media.

\section{Preparation of agar plates}

Preparation of agar plates was performed based on the method described by Ram Kumar and Pranay [25], with little modification. Nutrient agar was prepared according to manufacturer's instruction with $14 \mathrm{~g}$ of dried agar dissolved in $500 \mathrm{ml}$ distilled water. The agar solution was heated until boiling followed by sterilization in autoclave at $121^{\circ} \mathrm{C}$. The agar solution was then poured into a sterile petri plate and allowed to cool down and forming a gel. The plate was divided into eight sections by making a line marking on the outside surface of the plate. The eight sections were for each test samples namely $25 \mathrm{ppm}, 50 \mathrm{ppm}, 100 \mathrm{ppm}, 250 \mathrm{ppm}, 500 \mathrm{ppm}$ and $1000 \mathrm{ppm}$ samples, tetracycline $30 \mu \mathrm{g}$ (positive control) and methanol (negative control). The plate was sealed using parafilm and keep chilled at $4{ }^{\circ} \mathrm{C}$ upon bacteria inoculation.

\section{Preparation of bacteria broth}

Several selected bacteria were used to evaluate the antibacterial activities of the crude extracts of Leptadenia hastata. Escherichia coli, Salmonella typhi, Staphylococcus aureus and Klebsielia pneumonia were obtained from the stock culture provided by Virology Laboratory, University Malaysia Sarawak. The nutrient broth was prepared according to manufacturer's instruction, with $2.6 \mathrm{~g}$ of the dried broth dissolved in $200 \mathrm{ml}$ distilled water followed by sterilization in an autoclave at $121{ }^{\circ} \mathrm{C}$. The bacteria were subcultured in a $10 \mathrm{ml}$ of broth, each in a universal glass bottle for $16 \mathrm{~h}$ inside an incubator equipped with a shaker at $37^{\circ} \mathrm{C}[26]$.

After $16 \mathrm{~h}$ incubation, turbidity (optical density/OD) of the bacterial broth was measured by using UV mini spectrophotometer (model 1240 of Shimadzu brand), comparable to that of nutrient broth standard tube for further use [27]. The measurement was performed at wavelength $575 \mathrm{~nm}$ and the bacterial broth was ready to be used when its turbidity is between OD 0.6 to 0.9 . The nutrient broth was used to adjust the turbidity until the desired value was obtained.

\section{Plate inoculation}

Inoculation of the bacteria was carried out in a biohazard cabinet and the procedure was based on the method described by Ram Kumar and Pranay [26]. Approximately $1 \mathrm{ml}$ of the ready bacterial broth were transferred into mini centrifuge tubes. A sterile cotton swap was dipped into the mini centrifuge tube containing bacteria broth and streaked over entire of the agar plate surface, performed in 4 different directions. The agar plate was then left for 5-10 min before applying the test samples. The disc used was $6 \mathrm{~mm}$ diameter. A volume of the test samples of concentration $25 \mathrm{ppm}, 50 \mathrm{ppm}, 100 \mathrm{ppm}, 250 \mathrm{ppm}$, $500 \mathrm{ppm}$ and $1000 \mathrm{ppm}$ was each pupated onto the discs and placed onto the agar plate by using sterile forceps and gently pressed to ensure contact. Next to be placed on the agar plate was the disc pupated with methanol as a negative control, followed by $30 \mu \mathrm{g}$ of tetracycline as standard antibacterial agent (positive control). The plates were left at room temperature for $10 \mathrm{~min}$ to allow the diffusion of the test samples and the standards into the agar. Each crude extract was tested in triplicate for each bacterium used. The plate samples were then incubated at $37{ }^{\circ} \mathrm{C}$ for $24 \mathrm{~h}$ before the inhibition zone around every sample disc being examined. The inhibition zone was measured in diameter to indicate the presence of antibacterial activity for each sample, as compared to the positive control.

\section{Statistical analyses}

Values were expressed as mean \pm standard deviation for three determinations of each experiment. The analysis was done using the software-SPSS.

\section{RESULTS AND DISCUSSION}

\section{Antimicrobial activity}

The development of microbial resistance to presently available antibiotics has led to the search for new antimicrobial agents [16]. Due to the problem of microbial resistance to antibiotics, attention is given toward biologically active components isolated from plant species commonly used as herbal medicine, as they may offer a new source of antimicrobial activities [17]. Our search for antimicrobial bioactivity from tropical medicinal plant revealed the antimicrobial activity of five different solvent leaf extracts of Leptadenia hastata. Results of antimicrobial tests of the plant extracts are listed in table 1-4.

The extracts result as shown in table 1 do not show the much strong effect as when compared with the control, but it had some reasonable response in retarding the growth of the organism salmonella typhi.

In table 2 there is a progressive increase in the activities of the plant extracts on Escherichia coli with increase in the concentration of the solvent extract, this reflects a significant increase in the inhibition by $1.23 \pm 0.12 \mathrm{~mm}$ at $1000 \mathrm{ppm}$ with $(\mathrm{P}<0.05)$ in the mean value of chloroform, methanol and $1.20 \pm 0.10 \mathrm{~mm}$ at $500 \mathrm{ppm}$ ethyl acetate

In table 3 extract from dichloromethane at $1000 \mathrm{ppm}$ in the mean value of $1.33 \pm 0.06 \mathrm{~mm}$ showed higher activity against Staphylococcus aureus followed by methanol at $1.16 \pm 0.06 \mathrm{a}$ and chloroform $1.13 \pm 0.15 \mathrm{~mm}$ at the same concentration. The extracts present a significant antimicrobial activity but lower compared to the control. The association of antibiotics and plant extracts showed a substantial cooperation with the antibacterial activity against the bacteria. The results obtained with Staphylococcus aureus was particularly interesting since it was showing a gradual inhibition with increasing concentration with both polar and non-polar solvents extract. This inhibition was observed with the individual extracts and when it is used at higher concentrations.

In table 4 the results of effects of the leaf extract from various concentrations of hexane, ethyl acetate, dichloromethane, chloroform and methanol of Leptadenia hastata on the radial growth of Klebsielia pneumonia reveals growth is more inhibited at extract for hexane, dichloromethane, and ethyl acetate, they showed high activities against klebsielia pneumonia with the zone of inhibition of $0.50 \pm 0.00$ $\mathrm{mm}-1.23 \pm 0.06 \mathrm{~mm}$ from $25 \mathrm{ppm}, 50 \mathrm{ppm}, 100 \mathrm{ppm} 250 \mathrm{ppm} 500 \mathrm{ppm}$ and $1000 \mathrm{ppm}$ compared to chloroform and methanol extract with an inhibition rate of $0.60 \pm 0.01 \mathrm{~mm}-1.70 \pm 0.26 \mathrm{~mm}$. very low compared to the control $(2.08 \pm 0.01)$. The chloroform and methanol crude extract showed weak activities against Klebsielia pneumonia. However, the rate of inhibition increases with the increase in concentrations.

\section{Antibacterial activity}

Table 1: Effect of leaf extract of Leptadenia hastata on Salmonella typhi

\begin{tabular}{|c|c|c|c|c|c|c|c|}
\hline Extract & Control & $25 \mathrm{ppm}$ & 50 ppm & $100 \mathrm{ppm}$ & 250 ppm & 500 ppm & 1000 ppm \\
\hline Hexane & $2.06 \pm 0.01$ & $0.63 \pm 0.06^{b}$ & $0.70 \pm 0.00^{b}$ & $0.73 \pm 0.06^{b}$ & $0.83 \pm 0.12^{\mathbf{b}}$ & $0.87 \pm 0.23^{b}$ & $1.00 \pm 0.10^{b}$ \\
\hline Dichloromethane & $2.05 \pm 0.06$ & $0.55 \pm 0.07 b$ & $0.63 \pm 0.15^{b}$ & $0.67 \pm 0.15^{b}$ & $0.70 \pm 0.20^{\mathbf{b}}$ & $0.77 \pm 0.12^{\mathbf{b}}$ & $0.93 \pm 0.06^{b}$ \\
\hline Ethyl acetate & $2.07 \pm 0.02$ & $0.87 \pm 0.06^{\mathrm{ab}}$ & $0.87 \pm 0.06^{b}$ & $0.83 \pm 0.12^{\mathbf{b}}$ & $0.80 \pm 0.17 \mathbf{b}$ & $0.90 \pm 0.10^{\mathbf{b}}$ & $1.03 \pm 0.12^{\mathbf{b}}$ \\
\hline Chloroform & $2.06 \pm 0.01$ & $0.67 \pm 0.15^{b}$ & $0.67 \pm 0.06^{b}$ & $0.73 \pm 0.21^{b}$ & $0.77 \pm 0.66^{b}$ & $0.87 \pm 0.15^{b}$ & $1.03 \pm 0.06^{b}$ \\
\hline Methanol & $2.08 \pm 0.03$ & $0.87 \pm 0.12^{\mathrm{ab}}$ & $1.00 \pm 0.20^{\mathrm{ab}}$ & $0.93 \pm 0.06^{\mathrm{ab}}$ & $0.93 \pm 0.15^{\mathrm{ab}}$ & $0.97 \pm 0.06^{\mathrm{ab}}$ & $1.10 \pm 0.10^{\mathrm{ab}}$ \\
\hline
\end{tabular}

aSignificantly $(\mathrm{p}<0.05)$ higher compared to different extract at the same concentration, bignificantly $(\mathrm{p}<0.05)$ lower compared to the control 
Table 2: Effect of leaf extract of Leptadenia hastata on Escherichia coli

\begin{tabular}{|c|c|c|c|c|c|c|c|}
\hline Extract & Control & 25 ppm & $50 \mathrm{ppm}$ & $100 \mathrm{ppm}$ & $250 \mathrm{ppm}$ & $500 \mathrm{ppm}$ & 1000 ppm \\
\hline Hexane & $2.03 \pm 0.02$ & $0.43 \pm 0.06$ & $0.60 \pm 0.00$ & $0.73 \pm 0.06$ & $0.73 \pm 0.06$ & $0.83 \pm 0.06$ & $0.93 \pm 0.06$ \\
\hline Dichloromethane & $2.02 \pm 0.01$ & $0.47 \pm 0.06$ & $0.50 \pm 0.00$ & $0.70 \pm 0.10$ & $0.93 \pm 0.06 b$ & $1.03 \pm 0.06$ & $1.23 \pm 0.06$ \\
\hline Ethyl acetate & $2.03 \pm 0.00$ & $0.57 \pm 0.06 \mathrm{a}$ & $0.70 \pm 0.10$ & $0.80 \pm 0.10$ & $0.83 \pm 0.12$ & $1.20 \pm 0.10 \mathrm{~b}$ & $1.07 \pm 0.12 \mathrm{~b}$ \\
\hline Chloroform & $2.05 \pm 0.02$ & $0.47 \pm 0.15$ & $0.73 \pm 0.06 a$ & $0.83 \pm 0.06 a$ & $1.00 \pm 0.10$ & $1.07 \pm 0.06 \mathrm{~b}$ & $1.23 \pm 0.12 \mathrm{ab}$ \\
\hline Methanol & $2.05 \pm 0.01$ & $0.57 \pm 0.06 a$ & $0.70 \pm 0.00$ & $0.80 \pm 0.10$ & $1.03 \pm 0.06 \mathrm{a}$ & $1.30 \pm 0.10 \mathrm{a}$ & $1.23 \pm 0.12 \mathrm{ab}$ \\
\hline
\end{tabular}

aSignificantly $(\mathrm{p}<0.05)$ higher compared to different extract at the same concentration, bignificantly $(\mathrm{p}<0.05)$ lower compared to the control

Table 3: Effect of leaf extract of Leptadenia hastata on Staphylococcus aureus

\begin{tabular}{|c|c|c|c|c|c|c|c|}
\hline Extract & Control & 25 ppm & 50 ppm & 100 ppm & 250 ppm & 500 ppm & 1000 ppm \\
\hline Hexane & $2.04 \pm 0.02$ & $0.73 \pm 0.06 a$ & $0.93 \pm 0.15 a$ & $0.97 \pm 0.06$ & $1.03 \pm 0.06$ & $1.10 \pm 0.10$ & $1.27 \pm 0.06$ \\
\hline Dichloromethane & $2.05 \pm 0.01$ & $0.60 \pm 0.00 \mathrm{~b}$ & $0.90 \pm 0.10 \mathrm{~b}$ & $1.00 \pm 0.10 \mathrm{a}$ & $1.10 \pm 0.10 \mathrm{a}$ & $1.23 \pm 0.06 \mathrm{a}$ & $1.33 \pm 0.06 \mathrm{a}$ \\
\hline Ethyl acetate & $2.03 \pm 0.02$ & $0.67 \pm 0.06$ & $0.77 \pm 0.06$ & $0.87 \pm 0.6 b$ & $0.97 \pm 0.06$ & $1.03 \pm 0.06$ & $1.10 \pm 0.10 \mathrm{a}$ \\
\hline Chloroform & $2.04 \pm 0.01$ & $0.67 \pm 0.06$ & $0.80 \pm 0.10$ & $0.90 \pm 0.20$ & $1.03 \pm 0.12 b$ & $1.03 \pm 0.06$ & $1.13 \pm 0.15 \mathrm{a}$ \\
\hline Methanol & $2.06 \pm 0.01$ & $0.73 \pm 0.23$ & $0.60 \pm 0.00$ & $0.83 \pm 0.06$ & $1.03 \pm 0.06$ & $1.06 \pm 0.06 \mathrm{~b}$ & $1.16 \pm 0.06 \mathrm{a}$ \\
\hline
\end{tabular}

aSignificantly $(\mathrm{p}<0.05)$ higher compared to different extract at the same concentration, bSignificantly $(\mathrm{p}<0.05)$ lower compared to the control, the highest antimicrobial potentials were observed for the extracts

Table 4: Effect of leaf extract of Leptadenia hastata on Klebsielia Pneumonia

\begin{tabular}{|c|c|c|c|c|c|c|c|}
\hline Extract & Control & $25 \mathrm{ppm}$ & 50 ppm & 100 ppm & $250 \mathrm{ppm}$ & 500 ppm & 1000 ppm \\
\hline Hexane & $2.06 \pm 0.02$ & $0.60 \pm 0.00$ & $0.73 \pm 0.06$ & $0.80 \pm 0.10$ & $0.87 \pm 0.06$ & $0.97 \pm 0.06$ & $1.13 \pm 0.06$ \\
\hline Dichloromethane & $2.05 \pm 0.02$ & $0.57 \pm 0.06$ & $0.70 \pm 0.00$ & $0.77 \pm 0.06$ & $0.97 \pm 0.06$ & $1.00 \pm 0.10$ & $1.13 \pm 0.15$ \\
\hline Ethyl acetate & $2.07 \pm 0.01$ & $0.70 \pm 0.00$ & $0.83 \pm 0.06$ & $0.90 \pm 0.00$ & $1.00 \pm 0.00$ & $1.10 \pm 0.10$ & $1.23 \pm 0.06$ \\
\hline Chloroform & $2.05 \pm 0.02$ & $0.63 \pm 0.06$ & $0.70 \pm 0.17$ & $0.83 \pm 0.06$ & $1.03 \pm 0.12$ & $1.13 \pm 0.06$ & $1.07 \pm 0.21$ \\
\hline Methanol & $2.08 \pm 0.01$ & $0.63 \pm 0.12$ & $0.80 \pm 0.10$ & $0.77 \pm 0.21$ & $0.97 \pm 0.06$ & $1.07 \pm 0.06$ & $1.07 \pm 0.10$ \\
\hline
\end{tabular}

aSignificantly $(\mathrm{p}<0.05)$ higher compared to different extract at the same concentration, bSignificantly $(\mathrm{p}<0.05)$ lower compared to the control, $*$ All the values are mean \pm SD for three determinations.

\section{DISCUSSION}

The antimicrobial activity results of Leptadenia hastata extracts are summarized by the paper disc diffusion methods as shown in the tables above. The results of the disc diffusion method in terms of the size zone of inhibition $(\mathrm{mm})$ for the extracts were compared against the bacteria's studied.

The highest inhibitory activity was determined, methanolic extract showed the highest effect with a clearing zone of $1.10 \pm 0.10 \mathrm{~mm}^{\mathrm{ab}}$ and $0.97 \pm 0.06 \mathrm{~mm}^{\text {ab }}$ against salmonella typhi; relative to the control tetracycline (table 1). Salmonella enterica typhi, is an obligate parasite which leads to the development of typhoid fever [18]. In previous studies, Leptadenia hastata has been reported to play an important role in growth inhibition against bacteria, fungi, viruses, hypertension and tumors [19-22]. In agreement with the report of Alero and Wara [23] that Methanol and water extracts from the leaves of Leptadenia hastata showed antibacterial activities. However, the activity observed from the hexane, dichloromethane, ethyl acetate and chloroform were all active in ascending order when compared with the drug control. The action of Leptadenia hastata on Escherichia coli, and staphylococcus aureus is instructive. Although Escherichia coli belongs to the normal flora of humans, an enterohemorrhagic strain of Escherichia coli has caused serious food poisoning and preservatives, thus to eliminate its growth are needed [24]. The susceptibility of Staphylococcus aureus to the extract of this plant may be an indicator to its potential as a drug that can be used against this organism.

The growth of Staphylococcus aureus, Escherichia coli and Salmonella Para typhi was inhibited by the extracts at the tested concentration. The activity of this plant extracts against the Gramnegative bacteria is quite responsive, the methanol and chloroform extract were more active than the hexane, dichloromethane and ethyl acetate extracts with an increase in concentration. This result is, however, suggesting the possibility for the treatment of diseases caused by this microorganism; Staphylococcus aureus, Escherichia coli and Salmonella Para typhi.

\section{CONCLUSION}

The present work has proved that the extracts of leaves from (nhexane, dichloromethane, ethyl acetate, chloroform and methanol) possessed antimicrobial properties. The present results showed the potential of the medicinal plant used by traditional herbal medical practitioners as natural antimicrobial agents, thus can be further used to determine the bioactive natural products that may provide as leads in the development of new drugs. This study reconfirmed the potential of the objective to investigate the antibacterial potential of five crude extracts of Leptadenia hastata leaf usage in the treatment of bacterial diseases, and further studies are needed to determine the chemical identity of the bioactive compounds responsible for the observed antimicrobial activity. However, efforts are ongoing to characterize and explore the phytochemical properties of the contributory compounds present in the extract in University Malaysia (unimas).

\section{ACKNOWLEDGMENTS}

The author acknowledged the contribution of colleagues and all supports from the Natural product laboratory FRST/FSTS UNIMAS.

\section{AUTHORS CONTRIBUTIONS}

Isaac John Umaru; planned, execute and wrote the research manuscripts

Fasihuddin A. Badruddin; planned and supervised the research work Zaini B. Assim; proofreading of the manuscripts

Hauwa A. Umaru; contributed in the sample collection and preparation

\section{CONFLICTS OF INTERESTS}

All authors have none to declare

\section{REFERENCES}

1. Dubey N, Kumar R, Tripathi P. Global promotion of herbal medicines: India's opportunity. Curr Sci 2004;86:37-41. 
2. Ibrahim G, Odunze UO, Muhammad A. Phytochemical and antimicrobial studies on Vernonia blumeoides hook. Fil. (asteraceae) ethanol extract. Niger J Pharm Sci 2011;10:50-6.

3. Ghisalberti EL. Detection and isolation of bioactive natural products. In: Colgate SM, Molyneux RJ. eds. Bioactive Natural Products: Detection, Isolation and Structural Determination. CRC Press, USA; 1993.

4. Dias DA, Urban S, Roessner U. A historical overview of natural products in drug discovery. Metabolites 2012;2:303-6.

5. Kusuma IW, Arung ET, Rosamah E. Antidermatophyte and ant melanogenesis compound from Eleutherine Americana. Nat Med 2010;64:223-6.

6. Brahmachari G. Natural products in drug discovery: impacts and opportunities an assessment. Bioact Nat Prod 2011;18299. https://doi.org/10.1142/9789814335386_0001

7. Tamboura HH, Bayala B, Lompo M, Guissou IP, Sawadogo L. Ecological distribution, morphological characteristics and acute toxicity of aqueous extracts of Holarrhena floribunda (G. Don) durand and schinz, Leptadenia hastata (Pers.) Decne and Cassia sieberiana $(\mathrm{dc})$ used by veterinary healers in Burkina Faso. Afr J Traditional Cam 2005;2:13-24.

8. Aliero AA, Wara SH. Validating the medicinal potential of Leptadenia hastata. Afr J Pharm Pharmacol 2009;3:335-8.

9. Betti JL, Yemefa'a SRM, Nchembi Tarla F. Contribution to the knowledge of non-wood forest products of the ear north region of cameroon: medicinal plants sold in the kousseri market. J Ecol Nat Environ 2011;3:241-54.

10. Ibrahim HA, Ali GY, Halliru SN, Usaini S, Abdullahi II. Ethnobotanical survey of the wild edible food plants consumption among local communities in Kano State, NorthWestern, Nigeria. Int J Sci Technol 2012;2:713-7.

11. Dambatta S, Aliyu BS. A survey of major ethnomedicinal plants of Kano North Nigeria, their knowledge and uses by traditional healers. Bayero J Pure Appl Sci 2011;4:28-34.

12. Sena LP, Vanderjagt DJ, Rivera C, Tsin AT, Muhamad I, Millson M, et al. Analysis of nutritional component of eight famine foods of the republic of Niger. Plant Foods Human Nutr 1998;52:17-30.

13. Aquino R, Peluso G, De Tommasi N, De Simone F, Pizza C. New polyoxypregnane ester derivatives from Leptadenia hastata. J Natl Prod 1996;29:555-64.

14. Freiberger CE, Vanderjagt DJ, Pastuszyn A, Glew RS, Mounkaila G. Nutrient content of the edible leaves of seven wild plants from Niger. Plant Foods Human Nutr 1998;53:57-69.
15. Arbonnier M, Arbres. Arbustes et Lianes des Zones Sèches d'Afrique de l'Ouest. 1st Edn. CIRAD Publishers, Paris, ISBN; 2000. p. 2-87614-431-X, 541.

16. Kusuma IW, Arung ET, Rosamah E. Antidermatophyte and antimelanogenesis compound from Eleutherine. Am J Nat Med 2000;64:223-6.

17. Maiyo ZC, Ngure RM, Matasyo JC. Phytochemical constituents and antimicrobial activity of leaf extracts of three Amaranthus plant species. Afr J Biotechnol 2010;9:3178-82.

18. Efunwole 00, Adetuberu IA, Oladipupo OA, Abejoye OA. Antibacterial effect of Carica papaya against Salmonella typhi, the causative agent of Typhoid fever. IOSR J Environ Sci Toxicol Food Technol 2014;8:92-5.

19. Dambatta SH, Aliyu BS. A survey of major ethnomedicinal plants of Kano North Nigeria, their knowledge and uses by traditional healers. Bayero J Pure Appl Sci 2011;4:28-34.

20. Sutar NG, Pal SC. Evaluation of analgesic activity of leaf extracts of Pergularia daemia [Forsk] in experimental animals. Int J Pharm Sci 2014;6:137-9.

21. Patrick YH, Tchadjobo T, Koffi AG, Damehan T, Passimna P, Simplice DK, et al. Antibacterial activities of three latex plants of the asclepiadaceae family used in traditional medicine in South Togo. Int J Curr Microbiol Appl Sci 2015;4:882-91.

22. Thomas SD. Leptadenia hastata: a review of its traditional uses and its pharmacological activity. Med Chem 2012;2:148-50.

23. Aliero AA, Wara SH. Validating the medicinal potential of Leptadenia hastata. Afr J Pharm Pharmacol 2009;3:335-8.

24. Gulcin I. Antioxidant properties of resveratrol: a structure-activity insight. Innovative Food Sci Emerging Technol 2000;11:210-8.

25. Ram Kumar P, Pranay J. Comparative studies on the antimicrobial activity of black pepper (Piper nigrum) and turmeric (Curcuma longa) extracts. Int J Appl Biol Pharm Technol 2010;1:491-501.

26. Mahesh B, Satish S. Antimicrobial activity of some important medicinal plant against the plant and human pathogens. World J Agric Sci 2008;4:839-43.

27. Vandepitte J, Engback K, Piot P, Heuck CC. Basic microbiology procedures in clinical bacteriology. Geneva: World Health Organization; 1995. p. 85.

28. Kalaiselvan M, Gopalan R. Ethnobotanical studies on selected wild medicinal plants used by Irula tribes of the bolampatty valley, Nilgiri Biosphere reserve (NBR), Southern Western Ghants India. Asian J Pharm Sci Clin Res 2014;7 Suppl 1:22-6.

29. Sasikala RP, Sangeetha K, Meena KS. Comparative antibacterial and antifungal activities of benzene extract of three medicinal plants. Innovare J Life Sci 2017;5:3-5. 